\title{
ANALISIS EFEKTIFITAS DAN EFESIENSI TATA LETAK PABRIK TAHU SUPER AFIFAH DI KELURAHAN NUNU KECAMATAN TATANGA PALU BARAT
}

\author{
Arham \\ Asngadi \\ Syamsuddin \\ Program Studi Manajemen Fakultas Ekonomi Universitas Tadulako \\ Email: galangbunna21@gmail.com
}

\begin{abstract}
This study aims to analyze the effectiveness and efficiency of layout inTahu Super Afifah Factory in Nunu Village, Tatanga District, West Palu. The type of research used is quantitative research using line balancing method and travel chart. Result of research by using line balancing method obtained efficiency of tofu production process equal to 90,04\% with idle time 9,96\%. While the result of travel chart method obtained new design layout of production facility of factory know Super Afifah which more effective equal to 441,74 material flow load from initial layout equal to 627,38 material flow load. By comparison 185.64 material flow load or $29.58 \%$.
\end{abstract}

Keywords: layout, line balancing,travel chart

\section{ABSTRAK}

Penelitian ini bertujuan untuk menganalisis efektivitas dan efesiensi tata letak pada Pabrik Tahu Super Afifah di Kelurahan Nunu Kecamatan Tatanga Palu Barat. Jenis penelitian yang digunakan adalah penelitian kuantitatif dengan menggunakan metode line balancing dan travel chart. Hasil penelitian dengan menggunakan metode line balancing diperoleh efesiensi dari proses produksi tahu sebesar 90,04\% dengan waktu menganggur 9,96\%. Sedangkan hasil dari metode travel chart diperoleh rancangan baru tata letak fasilitas produksi pabrik tahu Super Afifah yang lebh efektif sebesar 441,74 beban aliran bahan dari tata letak mula-mula sebesar 627,38 beban aliran bahan dengan perbandingan 185,64 beban aliran bahan atau 29,58\%.

Kata Kunci: tata letak, line balancing, travel chart

\section{PENDAHULUAN}

Permasalahan yang dihadapi perusahaan dalam proses produksi sering dipengaruhi dengan rancangan tata letak yang kurang efektif terhadap proses produksi sebuah perusahaaan. Heizer dan Render (2010) tata letak merupakan salah satu keputusan yang menentukan efesiensi operasi perusahaan dalam jangka panjang, tata letak memiliki berbagai implikasi strategi karena tata letak menentukan daya saing perusahaan dalam kapasitas, proses, fleksibilitas, dan biaya serta mutu kehidupan kerja layout fasilitas produksi merupakan bentuk dan penempatan fasilitas-fasilitas yang diperlukan dalam proses produksi.

Pada umumnya tata letak pabrik yang terencana dengan baik akan ikut menentukan efisiensi dan akan menjaga kelangsungan hidup ataupun kesuksesan sebuah perusahaan. Peralatan produksi pabrik yang mahal harganya, peralatan yang canggih, dan suatu desain produk yang bagus akan tidak ada artinya akibat perencanaan layout yang tidak terencana dengan baik. Karena aktivitas produksi suatu produk secara normal harus berlangsung lama dengan tata letak yang berubah-ubah, maka setiap kekeliruan yang dibuat dalam perencanaan tata letak ini akan menyebabkan kerugian. Tujuan utama desain tata letak pabrik adalah untuk meminimalkan total biaya yaitu menyangkut biaya untuk konstruksi dan instalasi baik untuk bangunan mesin, maupun untuk fasilitas-fasilitas lainnya, material handling costs, biaya produksi, maintenance, safety, dan biaya penyimpanan produk setengah jadi. Hal ini tidak menjadi perhatian bagi kebanyakan usaha atau perusahaan, termasuk pada pabrik tahu Super Afifah yang merupakan salah satu usaha yang memproduksi tahu. 
Arham

Pabrik tahu Super Afifah merupakan sebuah usaha yang bergerak dalam bidang agroindustri, yaitu mengolah komoditas yang berupa kedelai menjadi tahu. Sehari pabrik tahu Super Afifah mampu menghabiskan \pm 2 ton bahan baku kedelai sehingga dalam sebulan pabrik tahu Super Afifah memproduksi 60-70 ton atau dalam perhari bisa menghasilkan 200 loyang tahu atau $2000 \mathrm{~kg}$ tahu. Seiring berjalannya waktu produk tahu Super Afifah terus mengalami peningkatan permintaan dari konsumen. Produk tahu Super Afifah sangat diminati konsumen dikarenakan harganya yang terjangkau, higenis, tidak menggunakan bahan pengawet, dan produk tahu Super Afifah tahan lama dibanding dengan produk Tahu lainnya yang ada di Kota Palu sehingga membuat pabrik tahu Super Afifah permintaannya semakin meningkat. Permintaanya tidak hanya berada di dalam Kota Palu, tetapi juga berada di Kabupaten Sigi, Pantai Barat, Pantai Timur, hingga ke Sulawesi Barat yaitu Mamuju.

\section{KAJIAN LITERATURE}

\section{Pengertian Tata Letak}

Tata letak merupakan satu keputusan penting yang menentukan sebuah operasi dalam jangka panjang. Tata memiliki banyak dampak srategis, karena tata letak menentukan daya saing perusahaan dalam hal kapasitas, proses, fleksibilitas dan biaya, serta kualitas lingkungan kerja, kontak pelanggan, dan citra perusahaan. Menurut Render dan Heizer (2010) tata letak merupakan salah satu keputusan yang menentukan efesiensi operasi perusahaan dalam jangka panjang, tata letak memiliki berbagai implikasi strategi karena tata letak menentukan daya saing perusahaan dalam kapasitas, proses, fleksibilitas, dan biaya serta mutu kehidupan kerja layout fasilitas prosuksi merupakan bentuk dan penempatan fasilitas-fasilitas yang diperlukan dalam proses produksi.

Menurut Wignjosoebroto (2003) tata letak pabrik (Plant layout) atau tata letak fasilitas (facilities layout) ialah sebagai tata cara pengaturan fasilitas-fasilitas pabrik guna menunjang proses produksi. Perencanaan tata letak mencakup desain atau konfigurasi dai bagian-bagian, pusat kerja, dan peralatan yang membentuk proses perubahan dari bahan mentah menjadi barang jadi. Pendapat tersebut, dapat dipahami bahwa layout adalah pengaturan letak bangunan, tata ruang, atau lorong yang menghubungkan antara bangunan yang satu dengan yang lain, serta pengaturan letak mesinmesin/peralatan yang berada dalam bangunan yang diperlukan dalam proses produksi.

\section{Efesien dan efektifitas}

Efisiensi dan efektifitas adalah dua konsep manajemen yang digunakan bentuk mengukur performance manajemen. Menurut Handoko (1998) bahwa efisiensi adalah kemampuan untuk menyelesaikan suatu pekerjaan dengan benar. Ini merupakan konsep matematik atau merupakan perhitungan ratio antara keluaran (output) dengan masukan (input) sedangkan efektifitas merupakan kemampuan untuk memilih tujuan yang cepat atau peralatan yang tepat untuk mencapai tujuan yang telah ditetapkan. Persaingan atau kompetisi yang semakin ketat, manajemen produksi selalu diharapkan untuk mencapai tingkat efisiensi dan efektifitas secara terus menerus seperti penyusunan tata letak peralatan pabrik perusahaan diarahkan agar supaya kegiatan produksi yang dilakukan dapat berjalan dengan tingkat efisiensi dan efektifitas yang tinggi.

\section{METODE PENELITIAN}

Metode kuantitatif yang digunakan dalam penelitian ini adalah metode Line Balancing dan Travel Chart. Line balancing yaitu proses pembagian pekerjaan kepada stasiun kerja sedemikian rupa sehingga diperoleh keseimbanggan setiap stasiun kerja (Subagyo, 2000). Sasaran Line balancing adalah menghasilkan pengelompokan tugas, seperti kebutuhan waktu yang kira-kira sama. Sasaran ini memerkecil waktu menganggur sepanjang kegiatan dan mengakibatkan pemanfaatan tenaga kerja dan peralatan yang tepat selama proses berlangsung. Untuk itu perlu dilakukan inventarisasi seperti pada jumlah kegiatan, kegiatan yang mendahului, waktu penyeselsaian setiap kegiatan, jumlah output yang 
diperlukan setiap hari dan waktu kerja setiap hari (Steveson dan Chuong, 2014). Selain itu juga, perlu ditentukan cycle time atau waktu siklus. Cycle time adalah waktu yang diperlukan untuk menyelesaikan satu unit produk pada satu stasiun kerja (Jacobs dan Chase, 2015).

Adapun rumus dari cycle time menurut Jacobs dan Chase (2015):

$$
\mathrm{C}_{\mathrm{t}}=\frac{60 X T}{D}
$$

Dimana:

$$
\begin{aligned}
\mathrm{C}_{\mathrm{t}} & =\text { Cycle time (waktu siklus) } \\
T & =\text { Waktu kerja perhari } \\
D & =\text { output yang diperlukan perhari (dalam satuan unit) }
\end{aligned}
$$

Adapun rumus mencari stasiun kerja $(N)$ menurut jacobs dan Chase (2015) :

$$
N=\frac{\Sigma \mathrm{t}}{\mathrm{C}_{\mathrm{t}}}
$$

Dimana:

$$
\begin{aligned}
& \boldsymbol{\Sigma} \mathrm{t}=\text { Jumlah waktu tugas } \\
& \mathrm{N}=\text { Stasiun kerja } \\
& \mathrm{C}_{\mathrm{t}}=\text { Cycle time }
\end{aligned}
$$

Selanjutnya untuk menentukan efesiensi menurut Reksohadiprodjo (1995) dapat menggunakan rumus:

$$
\text { Efesiensi }=\frac{\boldsymbol{\Sigma} \mathrm{t}}{\mathrm{N} \times \mathrm{Ct}}
$$

Dimana:

$$
\begin{aligned}
& \Sigma \mathrm{t}=\text { Jumlah waktu dari keseluruhan pekerjaan } \\
& \mathrm{N}=\text { Stasiun kerja } \\
& \mathrm{C}_{\mathrm{t}}=\text { Cycle time }
\end{aligned}
$$

Waktu lini pengerjaan diperoleh melalui operasi: $100 \%$ - Efesiensi

Kemudian untuk menentukan efektifitas tata letak menurut Reksohadiprodjo (1995):

Dimana:

$$
\begin{aligned}
& \mathrm{Lij}=\text { Jumlah beban yang dipindahkan dari } \mathrm{i} \text { ke } \mathrm{j} \\
& \mathrm{Dij}=\text { Jarak memindahkan beban antar bagian } \mathrm{i} \text { ke bagian } \mathrm{j}
\end{aligned}
$$

Sehubungan dengan hal ini, maka i dan $\mathrm{j}$ dalam penelitian ini dimaksudkan adalah :
a. Tempat bahan baku
b. Tempat penimbangan
c. Tempat perendaman
d. Tempat pencucian
e. Tempat penggilingan
f. Tempat perebusan
g. Tempat penyaringan 
Arham

h. Tempat penggumpalan

i. Tempat pencetakan

j. Tempat pemotongan

k. Tempat penyimpanan

Adapun rumus untuk mengetahui persentase peningkatan tingkat efektifitas tata letak dari setiap perubahan tata letak menurut Handoko (1998):

Dimana:

$$
\begin{aligned}
& \text { Eo }=\text { Efektifitas tata letak mula-mula } \\
& \text { En }=\text { Efektifitas tata letak rancangan }
\end{aligned}
$$

\section{HASIL DAN PEMBAHASAN}

\section{METODE LINE BALANCING}

\section{Cycle time dan Stasiun Kerja Pabrik Tahu Super Afifah}

Pada metode line balancing terlebih dahulu menentukan tempat atau pekerjaan dan waktu pelaksanaannya dari masing-masing tempat atau pekerjaan pada pabrik tahu Super Afifah. Jumlah output yang dihasilkan pabrik tahu Super Afifah yaitu $2.000 \mathrm{~kg}$ tahu menjadi 28.800 potongan tahu atau 200 loyang perhari dan untuk 1 chanel produksi pada pabrik tahu Super Afifah menghasilkan 6 talang yang nantinya menghasilkan 2 loyang tahu dengan waktu 77.8 menit. Waktu produktif yang digunakan tahu Super Afifah yaitu 12 jam per hari, serta jumlah tenaga kerja sebanyak 50 orang karywan. Penelitian ini berfokus pada 1 chanel produksi dari 12 chanel produksi yang ada pada pabrik tahu Super Afifah. Adapun jenis-jenis pekerjaan yang ada dalam proses produksi tahu Super Afifah adalah sebagai berikut:

\section{Tabel 1}

Komponen Pekerjaan, Pekerjaan yang Mendahului, dan Waktu Pelaksanaan

\begin{tabular}{|l|c|c|c|}
\hline \multicolumn{1}{|c|}{ Pekerjaan } & Kode & $\begin{array}{c}\text { Pekerjaan } \\
\text { Yang } \\
\text { Mendahului }\end{array}$ & $\begin{array}{c}\text { Waktu } \\
\text { Pelaksanaan } \\
\text { (Menit) }\end{array}$ \\
\hline Pengambilan Bahan baku & A & - & 0.34 \\
\hline Penimbangan & B & A & 0.19 \\
\hline Perendaman & C & B & 20.43 \\
\hline Pencucian & D & C & 0.86 \\
\hline Penggilingan & E & D & 13.52 \\
\hline Perebusan & F & E & 4.28 \\
\hline Penyaringan & G & F & 3.16 \\
\hline Penggumpalan & H & G & 18.27 \\
\hline Pencetakan & I & H & 7.89 \\
\hline Pemotongan & J & I & 2.72 \\
\hline Penyimpanan & K & J & 6.14 \\
\hline \multicolumn{2}{|l}{ Jumlah } & $\mathbf{7 7 . 8}$ \\
\hline
\end{tabular}

Sumber: Pabrik Tahu Super Afifah

Tabel 1 di atas dapat dilihat waktu pelaksanaan tertinggi yaitu pada proses perendaman bahan baku dimana waktu pelaksaannya 20,43 menit, hal ini dikarenakan bahan baku yaitu kedelai untuk menyerap air, agar ketika diolah pada proses penggilingan bahan baku lebih mudah diolah. Sedangkan 
untuk waktu pelaksanaan tercepat yaitu pada proses penimbangan dengan waktu pelaksanaan 0,19 menit, pada pekerjaan ini tidak memerlukan waktu lama karena tempat penimbangan berdekatan dengan gudang bahan baku sehingga proses pekerjaannya lebih cepat. Data tersebut dapat dibuat diagram network untuk menunjukan gerakan antara bagian dan identifikasi bagian yang aktif. Adapun diagram network tersebut dapat dilihat sebagai berikut:

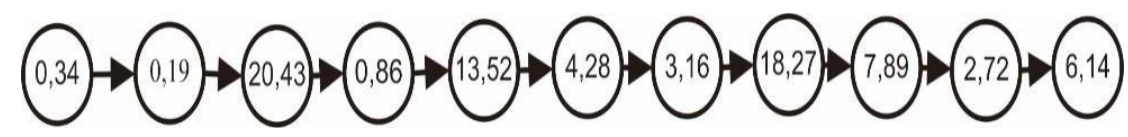

Gambar 1

Diagram Network Proses Produksi Tahu Super Afifah

Sumber: Tahu Super Afifah

Gambar 1 menunjukkan bahwa diagram dapat dihitung cycle time yaitu sebagai berikut:

Berdasarkan cycle time tersebut didapatkan waktu yang di peruntukan untuk setiap stasiun untuk menyelesaikan pekerjaan yaitu 21.6 menit. Setelah didapatkan cycle time, kemudian dilanjutkan dengan mencari jumlah stasiun dari jumlah waktu tugas dan cycle time yaitu sebagai berikut:

Berdasarkan hasil perhitungan antara jumlah waktu produksi dan hasil cycle time, maka didapatkan jumlah stasiun kerja sebanyak 4 stasiun kerja pada proses produksi pabri tahu Super Afifah.

\section{Perhitungan Efesiensi Pabrik Tahu Super Afifah}

Sebelum menentukan efesiensi dari tata letak pabrik tahu Super Afifah maka terlebih dahulu menentukan pekerjaan-pekerjaan yang tergabung dalam setiap stasiun kerja, maka dibuatkan matriks sebagai berikut:

Tabel 2

Matriks Stasiun Kerja

\begin{tabular}{|c|c|c|c|c|}
\hline $\begin{array}{c}\text { Stasiun } \\
\text { Kerja }\end{array}$ & Pekerjaan & $\begin{array}{c}\text { Waktu } \\
\text { (Menit) }\end{array}$ & $\begin{array}{c}\text { Sisa } \\
\text { (Menit) }\end{array}$ & $\begin{array}{c}\text { Pekerjaan yang dapat } \\
\text { dialokosikan }\end{array}$ \\
\hline \multirow{4}{*}{$\mathbf{1}$} & $\mathrm{A}$ & 0.34 & 21.26 & $\mathrm{~B}$ \\
\cline { 2 - 5 } & $\mathrm{B}$ & 0.19 & 21.07 & $\mathrm{C}$ \\
\cline { 2 - 5 } & $\mathrm{C}$ & 20,43 & $0.64($ idle $)$ & - \\
\hline \multirow{4}{*}{2} & $\mathrm{D}$ & 0,86 & 20.74 & $\mathrm{E}$ \\
\cline { 2 - 5 } & $\mathrm{E}$ & 13.52 & 7,22 & $\mathrm{~F}$ \\
\cline { 2 - 5 } & $\mathrm{F}$ & 4.28 & 2,94 & $\mathrm{~J}$ \\
\cline { 2 - 5 } & $\mathrm{J}$ & 2,72 & $0.22($ idle $)$ & - \\
\hline \multirow{2}{*}{3} & $\mathrm{G}$ & 3,16 & 18,44 & $\mathrm{H}$ \\
\cline { 2 - 5 } & $\mathrm{H}$ & 18,27 & $0.17($ idle $)$ & - \\
\hline \multirow{2}{*}{4} & $\mathrm{I}$ & 7.89 & 13.71 & $\mathrm{~K}$ \\
\cline { 2 - 5 } & $\mathrm{K}$ & 6.14 & $7.57($ idle $)$ & - \\
\hline
\end{tabular}

Sumber: Data Diolah Kembali 
Arham

Adapun perhitungan efesiensi tata letak pabrik pada tahu Super Afifah berdasarkan perhitungan stasiun kerja pada metode line balancing yaitu, jumlah stasiun kerja yang didapatkan adalah 4 (empat) stasiun, dimana jumlah waktu dari 4 stasiun tersebut adalah 86.4 menit $(4 \times 21.6)$ dengan waktu nganggur atau idle time sebesar 8,6 menit. Maka dapat diketahui tingkat efesien dengan cara membagi waktu tugas dengan seluruh waktu dari 4 stasiun yang dapat dilihat sebagai berikut:

Sedangkan untuk tingkat penganggurannya yaitu sebagai berikut:

Pengangguran: $100 \%-90.04 \%=9.96 \%$

\section{METODE TRAVEL CHART}

\section{Desain Tata Letak Fasilitas Pada Pabrik Tahu Super Afifah}

Tata letak fasilitas produksi harusnya dirancang untuk memungkinkan perpindahan yang ekonomis dari karywan dan bahan-bahan dalam proses produksi jarak perpindahan hendaknya sedekat mungkin serta peletakan bahan-bahan dan peralatan diminimumkan, untuk mencapai tempat kerja yang ideal dengan tujuan efektifitas produksi. Selain itu tempat kerja juga harus dipertimbangkan dalam mengatur jarak perpindahan bahan untuk mengurangi human error dan mengurangi tingkat kebosanan. Berdasarkan uraian di tersebut untuk memahami dengan jelas tata letak fasilitas produksi pada pabrik tahu Super Afifah dapat dilihat pada gambar sebagai berikut:

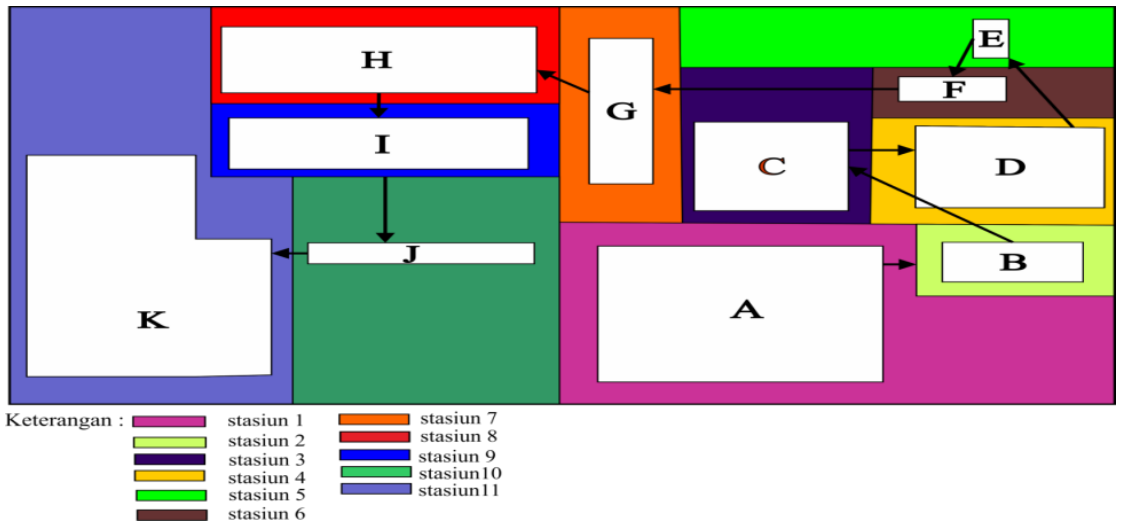

Gambar 2

Desain tata letak faasilitas produksi Pabrik Tahu Super Afifah

Sumber: Tahu Super Afifah

Keterangan:

$\begin{array}{ll}\longrightarrow & =\text { Aliran bahan } \\ \mathrm{A} & =\text { Tempat pengambilan bahan baku } \\ \mathrm{B} & =\text { Tempat Penimbangan bahan baku } \\ \mathrm{C} & =\text { Tempat perendaman } \\ \mathrm{D} & =\text { Tempat pencucian } \\ \mathrm{E} & =\text { Tempat penggilingan } \\ \mathrm{F} & =\text { Tempat perebusan } \\ \mathrm{G} & =\text { Tempat penyaringan } \\ \mathrm{H} & =\text { Tempat pengumpalan } \\ \mathrm{I} & =\text { Tempat pencetakan } \\ \mathrm{J} & =\text { Tempat pemotongan } \\ \mathrm{K} & =\text { Tempat penyimpanan }\end{array}$


Proses produksi tahu pada pabrik tahu Super Afifah memperlihatkan jalur atau jarak proses produksi dari satu fasilitas ke fasilitas yag lainnya, dimana jarak tersebut dapat di minimumkan menjadi berdekatan. Pada kaidah layout fasilitas produksi adanya jarak yang tidak berdekatan dari fasilitas satu ke fasilitas lainnya dalam perpindahan bahan menunjukan ke tidak efektifan tata letak (layout) fasilitas produksi yang di gunakan.

\section{Perhitungan Efektivitas Fasilitas Tata Letak Pabrik Tahu Super Afifah}

Mengidentifikasi perpindahan beban bahan dan jarak antar fasilitas, maka dapat di hitung tingkat efektivitas layout fasilitas produksi tahu pada pabrik tahu Super Afifah. Pada metode travel chart ada dua faktor kuantitatif yang di pertimbangkan yaitu jarak antara fasilitas dan beban yang dipindahkan antara satu fasilitas ke fasilitas lainnya. Hasil pengukuran jarak dan beban perpindahan bahan antar fasilitas produksi tahu pada pabrik tahu Super Afifah dapat dilihat sebagai berikut:

Tabel 3

Jarak Antara Fasilitas Produksi dan Beban Perpindahan Bahan

\begin{tabular}{|c|l|l|c|c|}
\hline No & \multicolumn{1}{|c|}{ Dari } & \multicolumn{1}{c|}{ Ke } & Jarak $(\mathbf{m})$ & Beban $(\mathbf{k g})$ \\
\hline $\mathbf{1}$ & Gudang bahan baku & Penimbangan & 0,72 & 50 \\
\hline $\mathbf{2}$ & Penimbangan & Perendaman & 3,7 & 13 \\
\hline $\mathbf{3}$ & Perendaman & Pencucian & 3,5 & 16 \\
\hline $\mathbf{4}$ & Pencucian & Penggilingan & 2,3 & 16 \\
\hline $\mathbf{5}$ & Penggilingan & Perebusan & 1,2 & 52 \\
\hline $\mathbf{6}$ & Perebusan & Penyaringan & 1,4 & 48 \\
\hline $\mathbf{7}$ & Penyaringan & Penggumpalan & 0,80 & 46 \\
\hline $\mathbf{8}$ & Penggumpalan & Pencetakan & 0,96 & 33 \\
\hline $\mathbf{9}$ & Pencetakan & Pemotongan & 1,1 & 20 \\
\hline $\mathbf{1 0}$ & Pemotongan & Penyimpanan & 9,4 & 24 \\
\hline
\end{tabular}

Sumber: Hasil pengukuran Fasilitas Produksi Pada Pabrik Tahu Super Afifah

Hasil pengukuran jarak perpindahan antar fasilitas dan beban perpindahan bahan tersebut dapat dilihat bahwa jarak tertinggi untuk proses pemindahan bahan baku ada pada fasilitas penyimpanan dengan jarak 9,4 meter, hal ini dikarenakan tempat pemotongan lebih didekatkan pada tempat pencetakan, sedangkan untuk beban perpindahan bahan tertinggi terdapat pada fasilitas gudang bahan baku yaitu dengan berat $50 \mathrm{~kg}$, dimana bahan baku tersebut dipindahkan tidak berdasarkan berat pengelolahan bahan baku persekali produksi namun dipindahkan dalam perkarung. Hasil pengukuran jarak antar bahan tersebut maka dapat dihitung tingkat efektifitas pada tata letak fasilitas produksi pada pabrik tahu Super Afifah pada tabel 4 sebagai berikut: 
Arham

Tabel 4

Perhitungan Efektivitas Tata Letak Fasilitas Produksi Pada Pabrik Tahu Super Afifah

\begin{tabular}{|l|l|c|c|c|}
\hline \multicolumn{1}{|c|}{ Dari } & \multicolumn{1}{c|}{ Ke } & Dij & Lij & Dij.Lij \\
\hline Gudang bahan baku & Penimbangan & 0,72 & 50 & 36 \\
\hline Penimbangan & Perendaman & 3,7 & 13 & 48,1 \\
\hline Perendaman & Pencucian & 3,5 & 16 & 56 \\
\hline Pencucian & Penggilingan & 2,3 & 16 & 36,8 \\
\hline Penggilingan & Perebusan & 1,2 & 52 & 62,4 \\
\hline Perebusan & Penyaringan & 1,4 & 48 & 67,2 \\
\hline Penyaringan & Penggumpalan & 0,80 & 46 & 36,8 \\
\hline Penggumpalan & Pencetakan & 0,96 & 33 & 31,68 \\
\hline Pencetakan & Pemotongan & 1,1 & 20 & 22 \\
\hline Pemotongan & Penyimpanan & 9,6 & 24 & 230,4 \\
\hline \multicolumn{4}{|c|}{ TOTAL } & $\mathbf{6 2 7 , 3 8}$ \\
\hline
\end{tabular}

Sumber: Hasil pengukuran Fasilitas Produksi Pada Pabrik Tahu Super Afifah (Diolah kembali)

Hasil perhitungan tersebut, maka dapat di ketahui efektivitas tata letak fasilitas pabrik tahu Super Afifah sebesar 627,38 beban aliran bahan. Terdapat 3 proses produksi yang memilki tingkat beban aliran bahan yang dapat dilihat pada tabel 4. Tata letak fasilitas produksi pada pabrik tahu Super Afifah dapat lebih efektif dengan cara mengusahakan jarak aliran bahan antara satu fasilitas ke fasilitas lain secara berdekatan. Terutama pada fasilitas produksi penggilingan ke perebusan, fasilitas produksi perebusan ke penyaringan dan fasilitas produksi pemotongan ke penyimpanan yang memiliki jarak yang beban angkutnya relatif tinggi atau berat.

\section{Rancangan Baru Tata Letak Fasilitas Produksi Pabrik Tahu Super Afifah}

Hasil analisis yang telah di uraikan pada bagian sebelumnya menunjukan bahwa tata letak fasilitas produksi tahu pada pabrik tahu Super Afifah masih belum efektif dan perlu ditingkatkan lagi, dimana jarak antara fasilitas satu dengan fasilitas lainnya masih cukup jauh. Untuk itu diperlukan relayout dengan mempertimbangkan jarak antara fasilitas dan beban perpindahan bahan serta tempat karyawan. Efektifitas produksi tata letak fasilitas yang akan didekatkan dapat tercapai. Hasil rancangan baru tata letak fasilitas produksi pabrik tahu Super Afifah dapat dilihat pada gambar sebagai berikut:

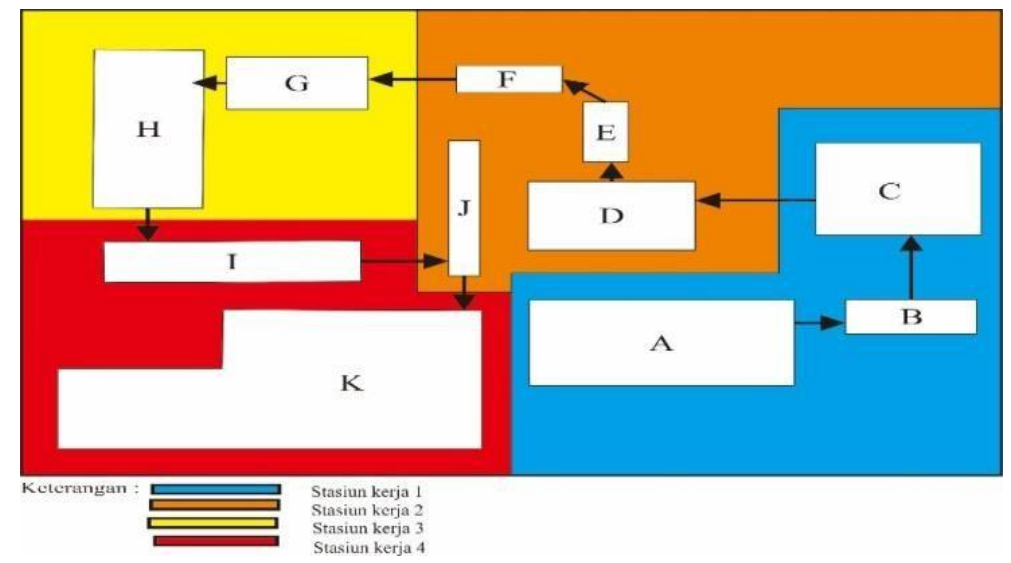

Gambar 3

Rancangan Baru Tata Letak Fasilitas Produksi Pada Pabrik Tahu Super Afifah Sumber: Hasil Rancangan Peneliti 


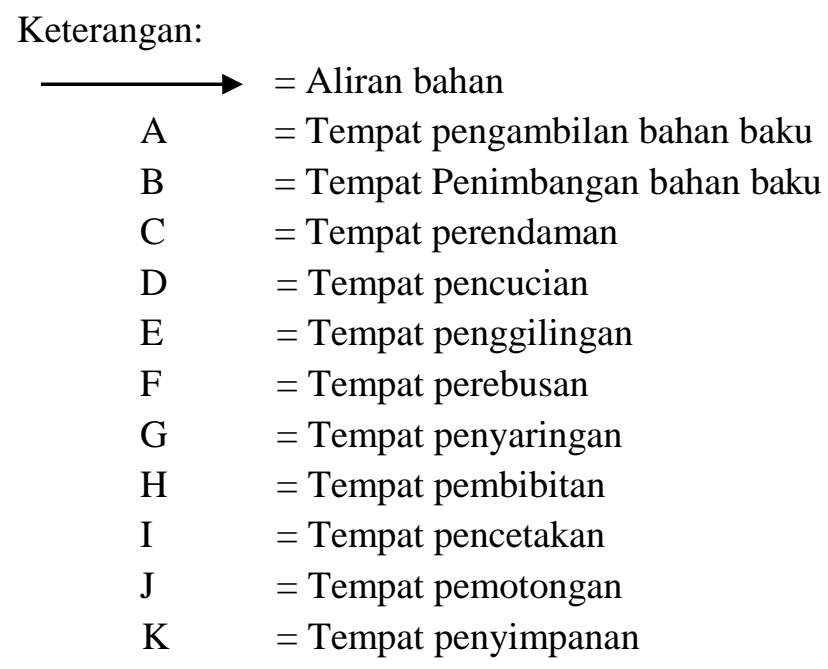

Tabel 5

Jarak Antara Fasilitas Produksi dan Beban Perpindahan Bahan Rancangan Baru Pabrik Tahu Super Afifah

\begin{tabular}{|c|l|l|c|c|}
\hline No & \multicolumn{1}{|c|}{ Dari } & \multicolumn{1}{|c|}{ Ke } & $\begin{array}{c}\text { Jarak } \\
(\mathbf{m})\end{array}$ & $\begin{array}{c}\text { Beban } \\
(\mathbf{k g})\end{array}$ \\
\hline $\mathbf{1}$ & Gudang bahan baku & Penimbangan & 0.72 & 50 \\
\hline $\mathbf{2}$ & Penimbangan & Perendaman & 1.5 & 13 \\
\hline $\mathbf{3}$ & Perendaman & Pencucian & 3.5 & 16 \\
\hline $\mathbf{4}$ & Pencucian & Penggilingan & 2.3 & 16 \\
\hline $\mathbf{5}$ & Penggilingan & Perebusan & 1.2 & 52 \\
\hline $\mathbf{6}$ & Perebusan & Penyaringan & 1.4 & 48 \\
\hline $\mathbf{7}$ & Penyaringan & Penggumpalan & 0.30 & 46 \\
\hline $\mathbf{8}$ & Penggumpalan & Pencetakan & 0.96 & 33 \\
\hline $\mathbf{9}$ & Pencetakan & Pemotongan & 0.5 & 20 \\
\hline $\mathbf{1 0}$ & Pemotongan & Penyimpanan & 5.14 & 24 \\
\hline
\end{tabular}

Sumber: Hasil Pengukuran (Diolah Kembali)

Pada tabel 5 di atas dapat dilihat hasil pengukuran hasil pengukuran jarak antara fasilitas produksi yang mengalami perubahan adalah jarak dari tempat penimbangan ke tempat perendaman yaitu 1,5 meter, jarak dari tempat penyaringan ke tempat penggumpalan yaitu 0,30 , jarak dari tempat pencetakan ke tempat pemotongan yaitu 0,5 dan jarak dari tempat pemotongan ke tempat penyimpanan yaitu 5,14 . Sedangkan untuk beban perpindahan tidak mengalami perubahan. Semakin tinggi nilai tersebut maka akan menunjukan semakin rendahnya tingkat efektivitas layout fasilitas produksi tersebut.

Pengurangan jarak antara fasilitas satu dengan fasilitas yang lainnya dapat dilakukan dengan mendekatkan atau menyusun peralatan yang mempunyai jarak yang cukup jauh dan beban yang relatif berat melalui proses coba-coba (trial and error). Hasil rancangan kembali tata letak dan pengukuran tersebut menunjukkan bahwa jarak antara fasilitas produksi menjadi berdekatan, kemudian menghitung kembali tingkat efektifitas pada rancangan baru dari tabel 5 yang dapat dilihat pada tabel 6 sebagai berikut: 
Arham

Tabel 6

Perhitungan Efektifitas Rancangan Baru Tata Letak Fasilitas Produksi Pabrik Tahu Super Afifah

\begin{tabular}{|l|l|c|c|c|}
\hline \multicolumn{1}{|c|}{ Dari } & \multicolumn{1}{c|}{ Ke } & Dij & Lij & Dij.Lij \\
\hline $\begin{array}{l}\text { Gudang bahan } \\
\text { baku }\end{array}$ & Penimbangan & 0.72 & 50 & 36 \\
\hline Penimbangan & Perendaman & 1.5 & 13 & 4.5 \\
\hline Perendaman & Pencucian & 3.5 & 16 & 56 \\
\hline Pencucian & Penggilingan & 2.3 & 16 & 36.8 \\
\hline Penggilingan & Perebusan & 1.2 & 52 & 62.4 \\
\hline Perebusan & Penyaringan & 1.4 & 48 & 67.2 \\
\hline Penyaringan & Penggumpalan & 0.30 & 46 & 13.8 \\
\hline Penggumpalan & Pencetakan & 0.96 & 33 & 31.68 \\
\hline Pencetakan & Pemotongan & 0,5 & 20 & 10 \\
\hline Pemotongan & Penyimpanan & 5.14 & 24 & 123.36 \\
\hline \multicolumn{2}{|c|}{ TOTAL } \\
\hline
\end{tabular}

Sumber: Hasil Pengukuran Rancangan Baru (Diolah Kembali

Perbandingan Tata Letak Mula-Mula dan Tata Letak Rancangan Baru Fasilitas Produks Pabrik Tahu Super Afifah

Hasil perhitungan sebelumnya menunjukan adanya perbandingan tingkat efektivitas dari tata letak fasilitas mula-mula dan tata letak fasilitas rancangan baru pada pabrik tahu Super Afifah. Untuk memperjelas perbandingan antara tata letak mula-mula dan tata letak rancangan baru pada fasilitas produksi pabrik tahu Super Afifah maka dibuatkan tabel perbandingan yang dapat dilihat sebagai berikut:

Tabel 7

Perbandingan Efektifitas Tata Letak Mula - Mula dan Tata Letak Rancangan Baru Fasilitas Produksi Pabrik Tahu Super Afifah

\begin{tabular}{|c|c|c|c|c|c|c|}
\hline \multirow{2}{*}{$\begin{array}{c}\text { Dari - } \\
\text { Ke }\end{array}$} & \multicolumn{2}{|c|}{$\begin{array}{c}\text { Jarak Antara fasilitas } \\
\text { (Dij) }\end{array}$} & \multicolumn{2}{c|}{$\begin{array}{c}\text { Jumlah Beban } \\
(\text { Lij) }\end{array}$} & \multicolumn{2}{c|}{ Efektifitas } \\
\cline { 2 - 7 } & Mula-mula & Rancangan & Mula-mula & Rancangan & Mula-mula & Rancangan \\
\hline A-B & 0,72 & 0.72 & 50 & 50 & 36 & 36 \\
\hline B-C & 3,7 & 1.5 & 13 & 13 & 48,1 & 4.5 \\
\hline C-D & 3,5 & 3.5 & 16 & 16 & 56 & 56 \\
\hline D-E & 2,3 & 2.3 & 16 & 16 & 36,8 & 36.8 \\
\hline E-F & 1,2 & 1.2 & 52 & 52 & 62,4 & 62.4 \\
\hline F-G & 1,4 & 1.4 & 48 & 48 & 67,2 & 67.2 \\
\hline G-H & 0,80 & 0.30 & 46 & 46 & 36,8 & 13.8 \\
\hline H-I & 0,96 & 0.96 & 33 & 33 & 31,68 & 31.68 \\
\hline I-J & 1,1 & 0.5 & 20 & 20 & 22 & 10 \\
\hline J-K & 9,4 & 5.14 & 24 & 24 & 230,4 & 123.36 \\
\hline \multicolumn{7}{|c|}{ Efektivitas (Dij.Lij) } \\
\hline
\end{tabular}

Sumber: Hasil Pengukuran (Diolah Kembali)

Berdasarkan tabel di atas dapat dilihat tingkat efektifitas tata letak mula-mula fasilitas produksi pada pabrik tahu Super Afifah yaitu 627,38 beban aliran bahan dan tingkat efektifitas tata letak rancangan baru pada fasilitas produksi pabrik tahu Super Afifah yaitu 441,74 beban aliran bahan. Pada 
tabel 7 dapat dilihat bahwa nilai beban aliran bahan dan tingkat efektifitas tata letak rancangan baru lebih rendah dengan perbedaan selisih 185,64 beban aliran bahan dari tata letak mula-mula.

Adapun untuk mengetahui persentase peningkatan tingkat efektifitas rancangan baru dari tata letak mula-mula yang dapat dilihat sebagai berikut:

Hasil perhitungan di atas menunjukkan jika tata letak rancangan baru diterapkan akan meningkatkan efektifitas tata letak fasilitas produksi sebesar 29,51\% atau 185,64 beban aliran bahan dari tata letak mula-mula. Diharapkan penelitian ini dapat menjadi alternatif pengambilan keputusan dalam meningkatkan hasil produksi pabrik tahu Super Afifah dengan cara melakukan penerapan tata letak rancangan baru ini yang telah diteliti tingkat efektifitasnya dengan menggunakan metode travel chart.

\section{KESIMPULAN DAN SARAN}

\section{Kesimpulan}

Berdasarkan hasil penelitian yang dilakukan, maka peneliti dapat menarik kesimpulan sebagai berikut:

1) Menggunakan metode line balancing diperoleh tingkat efisiensi dari proses produksi tahu pada Pabrik Super Afifah sebesar 90,04\% dan tingkat efektifitas pada fasilitas produksi Pabrik Tahu Super Afifah sebesar 627,38 beban aliran bahan.

2) Menggunakan metode line balancing pada proses produksi Pabrik Tahu Super Afifah sudah efesien dan dengan menggunakan metode travel chart untuk proses relayout tata letak fasilitas produksi pabrik Tahu Super Afifah di ruang efektifitas yang lebih tinggi.

\section{Saran}

Sehubungan dengan hasil penelitian, terdapat beberapa hal yang dapat disarankan kepada Tahu Super Afifah yaitu sebagai berikut:

1) Diharapkan penelitian ini dapat menjadi alternatif pengambilan keputusan dalam mengatur tata letak fasilitas produksi guna meningkatkan hasil produksi Tahu Super Afifah.

2) Pabrik Tahu Super Afifah harus dapat mempertahankan efisiensi proses produksi, mengingat permintaan yang meningkat dari konsumen terhadap produk tahu.

3) Agar dapat meningkatkan produksi Tahu diharapkan Pabrik Tahu Super Afifah melakukan pengaturan tata letak kembali (relayout) terhadap fasilitas produksinya dengan mempertimbangkan beban perpindahan bahan dan jarak antara fasilitas menjadi berdekatan terutama pada tempat perendaman, tempat penggumpalan, tempat pemotongan dan tempat penyimpanan.

\section{REFERENSI}

Handoko, T Hari, (1998). Dasar-Dasar Manejemen Produksi Dan Operasi Edisi Kesatu, BPFE

Yogyakarta. Yogyakarta.

Heizer, Jay And Render Barry, (2010). Operations Management-Manajemen Operasi, Edisi

Kesembilan, Salemba Empat. Jakarta

Jacobs, F. Robert dan Richard B. Chase, (2015). Manajemen Operasi dan Rantai Pasokan Operations and Supply Chain Management, $14^{\text {th }}$ Global Edition. Salemba Empat, Jakarta.

Subagyo, Pangestu. (2000). Manajemen Operasi, Edisi Pertama. BPFE, Yogyakarta. 
Arham

Rekshohadiprodjo, Sukanto (1995). Manajemen Produksi Dan Operasi, Edisi Ketiga Cetak Pertama, UGM - Yogyakarta.

Stevenson William J, dan Chee Choung (2014). Manajemen Operasi Perpektif Asia Operations Management an Asian Perspective, Edisi 9 Buku Pertama. Jakarta: Salemba Empat.

Wignjosoebroto, Sritomo, (2003). Tata Letak Dan Pemindahan Bahan. Edisi Ketiga, Guna Widya Surabaya. 